\title{
Global knowledge, local implications: a community college's response
}

\section{Marjorie Valentin, Margaret Stroup, Judith Donnelly}

Marjorie R. Valentin, Margaret H. Stroup, Judith F. Donnelly, "Global knowledge, local implications: a community college's response," Proc. SPIE 9664, Ninth International Topical Meeting on Education and Training in Optics and Photonics, 96641Q (24 October 2005); doi: 10.1117/12.2207690

SPIE Event: Ninth International Topical Meeting on Education and Training in Optics and Photonics, 2005, Marseille, France 
This paper is freely available as a resource for the optics and photonics education community.

\title{
Ref ETOP032
}

\section{Global Knowledge, Local Implications;A Community College's Response}

\author{
Marjorie R. Valentin, Margaret H. Stroup, Judith F. Donnelly
}

\begin{abstract}
Three Rivers Community College (TRCC), with federal funding, provided a customized laser program for Joining Technologies in Connecticut, which offers world-class resources for welding and joining applications. This program addresses the shortage of skilled labor in the laser arena, lack of knowledge of fundamental science of applied light, and an increase in nonperforming product. Hiring and retraining a skilled workforce are important and costly issues facing todayl's small manufacturing companies.
\end{abstract}

\section{Summary}

TRCC, located in Norwich, Connecticut, is a commuter college, accredited by the Connecticut Board of Governors for Higher Education, the New England Association of Schools and Colleges (NEASC), and the Technology Accreditation Commission of the Accreditation Board for Engineering and Technology (TAC-ABET). TRCC is an integral partner in Connecticut's economic and workforce development initiatives, bringing three decades of expertise serving diverse populations of the region by improving their quality of life through education.

In June, 1997, TRCC received approval to offer Connecticut's only associate degree program in Photonics Engineering Technology and has received extensive support from the National Science Foundation (NSF) for its Fiber Optics Association (FAO) approved lab and an Award for Educational Innovation from TAC-ABET. In December 2000, TRCC's 15.5-credit Fiber Optic Certificate was approved. In January 2001, the certificate was revised and approved at 14.5credits to accommodate distance learning and incumbent worker training.

TRCC has collaborated with the Connecticut Business and Industry Association (CBIA) on numerous initiatives. In the fall of 2002, CBIA received a $\$ 2.2$ million Incumbent Worker/Dislocated Worker Skills Shortage II Demonstration grant from the United States Department of Labor (USDOL) to train incumbent workers within the state's manufacturing and laser/fiber optic/telecommunications industries. The purpose of the grant was to address skill shortages in these industries so that both the workers and their employing companies remain competitive.

Joining Technologies, located in East Granby, CT, was one of the companies identified by CBIA in the fiber optics cluster, as a high-need company that would profit from advanced education and training. Joining Technologies quality management system is modeled and certified in accordance with the AS9100 \& ISO 9001:2000 quality standards. Joining Technologies offers material joining engineering including joint design, materials process selection, tooling, and automation utilizing a versatile multi-axis lathe system. The applications are designed for Nd:YAG laser and transferred arc welding. With over 20 years of experience, Joining Technologies is an integral metallurgical lab for instant verification in addition to their met lab. Joining Technologies is focused on both material science and research and development. In 2001, Joining Technologies earned a prestigious gold award from the Connecticut Capital 
Breakthrough Quality on the integration of robots for high production $p$ rocessing of computer stampings. The company is currently pursing development of laser cladding and engineering. Joining Technologies has extensive electron beam welding knowledge and is a member of the US Microscopic Welding Association.

CBIA identified TRCC as a crucial cluster partner that has the flexibility to respond quickly to industry training needs. TRCC has a high-level of cluster-based expertise in the fiber-optic field of education and training. Consequently, CBIA solicited Professor Judith F. Donnelly, and TRCC's Department of Business \& Industry Services to meet with a company that was in dire need of advanced education and training for its incumbent workforce. At the initial meeting several issues arose in the following categories: shortage of skilled labor in laser arena; existing training was piecemeal at best, due to a lack of resources; laser technicians lacked knowledge of fundamental science of applied light; large volume product re-work as a result of customer feedback and complaints; in medical devices area, the inability to meet the K factor statistical deviation tolerances can shut the line down, this was another critical area in need of attention; and safety issues were are unders tood only at a minimal level. The company considered the implications of NOT implementing training and determined that growth would stagnate and ability to compete on projects, especially in aerospace, industry would be severely compromised. Additionally, the continued increase in and subsequent expenses of product redo's would imperil the companyl's survival.

After careful consideration of these alternatives, the company determined training was the best option and developed specific training outcomes: decrease non-performing product by $10 \%$; decrease learning curve for employees; and create a work environment conducive to crosstraining employees.

Joining Technologies, CBIA, and TRCC determined the effective measurement of training outcomes. After numerous meetings the following measures were instituted: employee quarterly report cards reflect quality issues and can be used as metrics; and the percentage of non-performing product can be measured and compared pre-and-post training. The educational training program targeted 8 machine operators and 3-4 assembly techs +3 supervisors. Additionally, the president, marketing director and vice-president of Joining Technologies also participated in the training. Some of the characteristics of the targeted employees were: new employees had little to no training; all but one employee worked first shift, and one was employed on second shift.

Training logistics were determined as well. These included: training vendor would be TRCC; the curriculum would be designed and implemented by Professor Donnelly; training would be held at Joining Technologies conference room; and employees would be paid for all of perhaps $1 / 2$ of training time (company match required by CBIA). Due to the nature of the funding source, the program encountered cost and time constraints, this situation necessitated a rapid response by TRCC, Joining Technologies and CBIA at all levels. The training was customized by Professor Donnelly utilizing best practices from previously implemented successful programs, with a keen awareness of Joining Technologiesl' unique position within the photonics spectrum of business and industry. Program implementation required considerable travel by all the partners involved to meet learner needs. In addition to hosting the training and subsidizing employee pay, Joining Technologies provided dinner for all 8-sections, 
in order to provide continuity and easy transition for employees as well as supplies for all students. The 8-sections focused on the following topics for a total of 24-classroom hours: characteristics of laser light verses regular light; laser safety; laser hazards; irradiance; nature and behavior of light; wave parameters, diffraction; fibers, mirrors and lenses; optical fiber; collimation and focusing; laser physics; metastable state; emission; TEM modes; pulse repletion frequency laser output characteristics and applications.

In summary, the training served 15 employees at a total cost of $\$ 7,833$. Overall, all 15 successfully completed the course, and the president of the company, who participated, was extremely pleased with the collaboration and rapid response provided for Joining Technologies to enable them to be more productive and remain competitive within the industry. 